\title{
Profiling of Nondigestible Carbohydrate Products in a Complete Set of Alien Monosomic Addition Lines Explains Genetic Controls of Its Metabolisms in Allium cepa
}

\author{
Shigenori Yaguchi and Tetsuya Nakajima \\ Department of Biological and Environmental Sciences, Faculty of Agriculture, Yamaguchi University, \\ 1677-1 Yoshida, Yamaguchi-shi, Yamaguchi 753-8515, Japan \\ Toshihisa Sumi \\ Department of Bioengineering, Yatsushiro National College of Technology, 2627 Hirayama-Shin- \\ Machi, Yatsushiro, Kumamoto 866-8501, Japan \\ Naoki Yamauchi and Masayoshi Shigyo ${ }^{1}$ \\ Department of Biological and Environmental Sciences, Faculty of Agriculture, Yamaguchi University, \\ 1677-1 Yoshida, Yamaguchi-shi, Yamaguchi 753-8515, Japan
}

\begin{abstract}
Additional Index wORDs. Allium fistulosum, pectin methylesterase, polygalactronase, shallot
Abstract. Eight kinds of japanese bunching onion [Allium fistulosum L. (genomes FF)]-shallot [Allium cepa L. Aggregatum group (genomes AA)] monosomic addition line [MAL (FF+1A-FF+8A)] were used to study the effects of single alien chromosomes from $A$. cepa on the production of carbohydrates in the leaf tissues of $A$. fistulosum. Carbohydrate contents in green leaf blades of these MALs were measured during alternate months from May 2005 to Mar. 2006. The determination of soluble sugar content from leaf blades of each MAL and $A$. fistulosum revealed that nonreducing sugars (sucrose and fructan) accumulated in winter leaf blades. Reducing sugar (fructose) in the leaf blades of each MAL was lower than $A$. fistulosum in almost every time period. In the leaf blades of $\mathrm{FF}+4 \mathrm{~A}$, high fructan accumulation was observed from Nov. 2005 to Mar. 2006. A series of determinations on the pectin content showed that amounts of $\mathrm{NaOH}$-soluble pectin and $\mathrm{HCl}$-soluble pectin remained at low levels at all time periods. High pectin accumulations in $\mathbf{F F}+7 \mathrm{~A}$ and $\mathrm{FF}+8 \mathrm{~A}$ occurred in September and slightly decreased in November. A decrease in hexametaphosphoric acid-soluble pectin content was associated with the maturity of MALs from autumn to winter, whereas the water-soluble pectin content increased. The pectin methylesterase and polygalactronase genes of shallot were assigned to chromosome $7 \mathrm{~A}$ and $4 \mathrm{~A}$, respectively. These results demonstrate that important genes related to pectin metabolism in shallot are located on chromosomes $4 \mathrm{~A}$, 7A, and $8 \mathrm{~A}$ of shallot.
\end{abstract}

Pectins are sources of dietary fiber and are basically galacturonic acid polymers (Ridley et al., 2001). The health effects of pectin substances are receiving increasing interest (Willats et al., 2006). It is generally accepted that a high-fiber diet is beneficial to human health and that pectin is an important soluble fiber in fruit and vegetables. There is clear evidence that pectin can lower cholesterol and serum glucose levels, and that it may also have anticancer properties (Behall and Reiser, 1986; Yamada, 1996). Pectin and pectic oligosaccharides have been shown to induce apoptosis in human colonic adenocarcinoma cells (Olano-Martin et al., 2003).

Although the health-enhancing effects of pectin substances are widely known, the study of pectin biosynthesis is challenging, and progress in this area has been slow (Ridley et al., 2001). The textures of vegetables and fruit are affected by pectin

\footnotetext{
Received for publication 26 June 2009. Accepted for publication 31 Aug. 2009 This study was supported by a Grant-in-Aid for Scientific Research (C) (No. 19580032) from the Ministry of Education, Science, Sports, and Culture of Japan. The genetic marker development was supported by a Research Project for Utilizing Advanced Technologies in Agriculture, Forestry and Fisheries'. We thank Michael J. Havey of Agricultural Research Service, U.S. Department of Agriculture and University of Wisconsin, for critically reviewing this manuscript.

${ }^{1}$ Corresponding author. E-mail: shigyo@yamaguchi-u.ac.jp.
}

substances (Femenia et al., 1998; Sapers et al., 1997). Several studies have shown that the degradation of pectin substances is related to the softening of vegetable tissues (Brady, 1987; Campbell et al., 1990; Huber, 1983; Sakurai and Nevins, 1993). For the reasons reported above, the amount of pectin in the leaf blades (green leaves) of japanese bunching onion [Allium fistulosum (genomes FF)] greatly affects its quality in terms of texture and health-promoting effects.

We previously developed eight A. fistulosum-shallot [A. cepa Aggregatum group (genomes AA)] monosomic addition lines (MAL; $2 n=2 x+1=17, \mathrm{FF}+1 \mathrm{~A}-\mathrm{FF}+8 \mathrm{~A}$ ) that display morphological and physiological characteristics different from those of the A. fistulosum parent (Shigyo et al., 1997), likely due to alien gene or genes on the extra chromosome from the shallot. Studies using these lines have revealed that several lines with alien chromosomes, which possess the key regulatory and structural genes for carbohydrate metabolism, show large differences in the nonreducing sugar components (Hang et al., 2004; Yaguchi et al., 2008b).

The aims of the present study were to reveal seasonal changes in the pectin content of A. fistulosum and to determine chromosomal locations of shallot genes important for pectin metabolism by means of biochemical and genetic studies in A. fistulosum-shallot MALs. In this study, pectin contents in 
a complete set of MALs were evaluated over time to determine the effect of a single alien chromosome from the shallot on pectin accumulations in $A$. fistulosum.

\section{Materials and Methods}

Plant materials. The plant materials were a complete set of A. fistulosum-shallot MALs $(2 n=2 x+1=17, \mathrm{FF}+1 \mathrm{~A}-\mathrm{FF}+8 \mathrm{~A})$ and a control plant, 'Kujyo-hoso' japanese bunching onion $(2 n=2 x=16, \mathrm{FF})$. The MALs were produced via the backcrossing of allotriploids [FFA (female)], between $A$. fistulosum 'Kujyo-hoso' and shallot 'Chiang mai', to A. fistulosum 'Kujyo-hoso' (male) (Shigyo et al., 1996). The experimental design used single replicates of eight MALs and a control. Cultivation and fertilizer applications were carried out as described by Shigyo et al. (1997). A row $(1.5 \times 21.9 \mathrm{~m})$ with silver mulching was prepared by making 288 holes (four lines $\times$ eight columns per line) with 0.3-m spacing between each hole. Thirty-two clones of each MAL and $A$. fistulosum were grown in an experimental field at Yamaguchi University (lat. $34^{\circ} \mathrm{N}$, long. $\left.131^{\circ} \mathrm{E}\right)$ from May 2005 to Mar. 2006. Liquid fertilizer (6.5N6P-19K; HYPONeX Japan, Osaka, Japan) $\times 1000$ solution was applied at weekly intervals with irrigation to each plant to ensure uniform growth. Healthy mature leaf blade tissue of the same growth stage in each MAL was sampled from the youngest fully expanded leaf of developing plants. Once plants were sampled, those plants were avoided being sampled again in the next sampling period, and were then used again for conforming to the growth stage of the other plants. The following extractions and determinations were replicated twice.

EXTRACTION AND PRESERVATION OF PECTIN. Tissue extraction was performed in alternate months from May 2005 to Mar. 2006. Leaf blade tissues (20.0 g) from three or more plants of one strain were sliced to reduce particle size to less than $5 \mathrm{~mm}$. The tissues were combined and transferred into boiling ethanol (final concentration of $70 \%$ ) for $15 \mathrm{~min}$. The boiled tissues were homogenized in a Universal homogenizer (Nihon Seiki Seisakusyo, Tokyo) with the boiling ethanol. The homogenate was filtered through a No. 2 filter paper (ADVANTEC, Tokyo). The filtrate was used for the determination of sugars and ethanol-soluble pectin (EtOH-P). The residue was homogenized three times in $70 \%$ ethanol and boiled for $15 \mathrm{~min}$. The residue was washed with acetone and air-dried in a fume hood as alcohol-insoluble solids (AIS).

Sequential EXtraction OF PECTIN With DifFerent SOLUBILITY. AIS $(0.1 \mathrm{~g})$ was suspended in water $(50 \mathrm{~mL})$, stirred for $15 \mathrm{~min}$, and then left to stand one night at room temperature. The homogenate was filtered through a funnel fused-in fritted glass disc (11G-3, micropore diameter 20-30 $\mu \mathrm{m}$;
Sansyo, Tokyo). The filtrate was used as water-soluble pectin (WP). The water-insoluble residue was further extracted in $0.4 \%$ hexametaphosphoric acid $(50 \mathrm{~mL})$ for $1 \mathrm{~h}$ at $80{ }^{\circ} \mathrm{C}$. The filtrate was used as hexametaphosphoric acid-soluble pectin (HMP). The hexametaphosphoric acid-insoluble residue was then extracted in $0.05 \mathrm{~N} \mathrm{HCl}(50 \mathrm{~mL})$ for $1 \mathrm{~h}$ at $100{ }^{\circ} \mathrm{C}$. The filtrate was used as $\mathrm{HCl}-$ soluble pectin ( $\mathrm{HCl}-\mathrm{P})$. The $\mathrm{HCl}-$ insoluble residue was finally extracted in $4 \% \mathrm{NaOH}(50 \mathrm{~mL})$ overnight at room temperature. The filtrate was used as $\mathrm{NaOH}-$ soluble pectin ( $\mathrm{NaOH}-\mathrm{P})$.

DETERMinATION OF ALCOHOL-SOLUBLE CARBOHYDRATE AND PECTIN CONTENTS. Free fructose in 70\% ethanol extracts was determined by the thiobarbituric acid method (Percheron, 1962). To determine fructan plus sucrose, free fructose was removed from extracts by heating a 20 - $\mathrm{L}$ aliquot in $1 \mathrm{~N} \mathrm{NaOH}$ at $100{ }^{\circ} \mathrm{C}$ for $10 \mathrm{~min}$ and then assaying for released fructose. To determine fructan alone, sucrose was first removed by digestion with invertase. A $20-\mu \mathrm{L}$ aliquot of extract was incubated with $10 \mu \mathrm{L}$ of $2 \mathrm{mg} \cdot \mathrm{mL}^{-1}$ invertase (bakers yeast; Sigma, St. Louis) and $10 \mu \mathrm{L}$ of $25 \mathrm{~mm}$ ammonium acetate buffer ( $\mathrm{pH} 5.5$ ) for $5 \mathrm{~min}$ and was then assayed to determine released fructose. The released fructose was determined by the thiobarbituric acid method.

Before the determination of pectin content, $5 \mathrm{~mL}$ of EtOH-P, WP, HMP, and HCl-P was saponified in $0.02 \mathrm{~N} \mathrm{NaOH}(5 \mathrm{~mL})$ for $30 \mathrm{~min}$ at room temperature. The pectin contents were colorimetrically determined by the carbazol-sulfuric acid method (Filisetti-Cozzi and Carpita, 1991) as D-galacturonic acid. The carbazole-sulfuric acid method was performed in a test tube on $0.2-\mathrm{mL}$ saponified samples and $0.2 \mathrm{~mL}$ of $\mathrm{NaOH}-\mathrm{P}$. To analyze the sample, $1.2 \mathrm{~mL}$ of $25 \mathrm{~mm}$ sodium tetraborate (in $\mathrm{H}_{2} \mathrm{SO}_{4}$ ) was added. The tube was placed in a boiling water bath for $10 \mathrm{~min}$ followed by cooling in an ice-water bath until room temperature was reached. When the mixture reached $20{ }^{\circ} \mathrm{C}$, $40 \mu \mathrm{L}$ of the carbazole reagent $[0.125 \%(\mathrm{w} / \mathrm{v})$ of carbazole in EtOH] was added. The tube was placed in a boiling water bath for $15 \mathrm{~min}$ followed by cooling in an ice-water bath until $20^{\circ} \mathrm{C}$ was reached. The light absorbance of the solution at $530 \mathrm{~nm}$ was measured.

DNA isolation. The total genomic DNA of two complete sets of A. fistulosum-shallot MALs and control plants was isolated from fresh leaf tissue using a mini-prep DNA isolation method (van Heusden et al., 2000).

Polymerase Chain Reaction (PCR) Primer design. Nested primer sets were designed with the software GENETYX 6.1.3 (Genetyx, Tokyo) to amplify regions from pectin methylesterase (PME) and polygalacturonase (PG) based on cDNA sequences, with GenBank accession nos. CF442750 and CF451451 for PME and GenBank accession no. CF452289 for PG. The primer sequences are shown in Table 1. PME

Table 1. PCR primer sets used in this study to identify chromosomal locations of the genes related to the pectin metabolisms.

\begin{tabular}{|c|c|c|c|c|}
\hline Primer set ${ }^{\mathrm{z}}$ & GenBank accession no. & PCR & Forward and reverse primers $\left(5^{\prime}-3^{\prime}\right)$ & Annealing temp. $\left({ }^{\circ} \mathrm{C}\right)$ \\
\hline \multirow[t]{3}{*}{ PME } & CF442750/ CF451451 & First & TGTAATTCCCTTGCCATGACC & 60 \\
\hline & & & AGCATTGCCGAAGATAAAGTCC & \\
\hline & & Second & CACGGCTGCAACGATAGTGG & 65 \\
\hline \multirow[t]{3}{*}{ PG } & CF452289 & First & GGAAGAGGAGAAGCCTTGTG & 58 \\
\hline & & & CTGATTTTAGTCCCATTCATCGTC & \\
\hline & & Second & TCTCTTTTGTTCAGCGATTCGAAG & 58 \\
\hline
\end{tabular}

${ }^{\mathrm{z}} \mathrm{PME}=$ pectin methylesterase, $\mathrm{PG}=$ polygalactronase. 
Table 2. Carbohydrates content in Allium fistulosum (FF) and eight monosomic addition lines (FF+1A-FF+8A) from May 2005 to Mar. 2006.

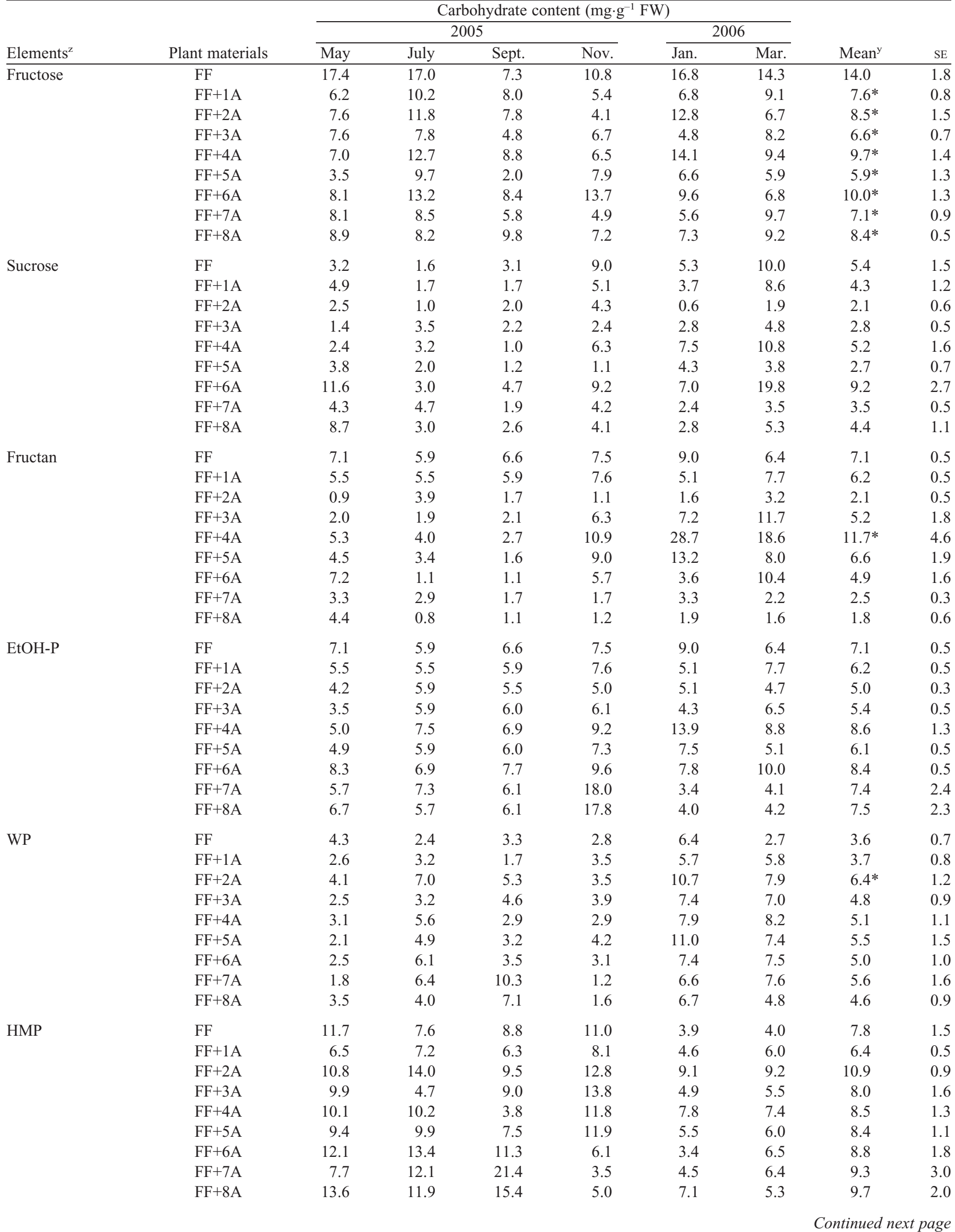


Table 2. Continued.

\begin{tabular}{|c|c|c|c|c|c|c|c|c|c|}
\hline \multirow[b]{3}{*}{ Elements $^{\mathrm{z}}$} & \multirow[b]{3}{*}{ Plant materials } & \multicolumn{6}{|c|}{ Carbohydrate content $\left(\mathrm{mg} \cdot \mathrm{g}^{-1} \mathrm{FW}\right)$} & \multirow[b]{3}{*}{ Mean $^{\mathrm{y}}$} & \multirow[b]{3}{*}{ SE } \\
\hline & & \multicolumn{4}{|c|}{2005} & \multicolumn{2}{|c|}{2006} & & \\
\hline & & May & July & Sept. & Nov. & Jan. & Mar. & & \\
\hline \multirow[t]{6}{*}{ HCl-P } & $\mathrm{FF}$ & 3.5 & 1.5 & 2.6 & 2.8 & 3.2 & 1.9 & 2.6 & 0.3 \\
\hline & $\mathrm{FF}+2 \mathrm{~A}$ & 1.5 & 2.9 & 4.1 & 4.5 & 2.6 & 3.3 & 3.2 & 0.5 \\
\hline & $\mathrm{FF}+3 \mathrm{~A}$ & 2.0 & 1.3 & 3.9 & 4.1 & 2.3 & 2.1 & 2.6 & 0.5 \\
\hline & $\mathrm{FF}+6 \mathrm{~A}$ & 2.6 & 3.2 & 4.8 & 2.6 & 2.5 & 3.3 & 3.2 & 0.4 \\
\hline & $\mathrm{FF}+7 \mathrm{~A}$ & 1.4 & 3.3 & 9.3 & 0.9 & 1.9 & 2.9 & 3.3 & 1.4 \\
\hline & $\mathrm{FF}+8 \mathrm{~A}$ & 2.8 & 2.5 & 6.7 & 1.3 & 1.9 & 2.4 & 2.9 & 0.9 \\
\hline \multirow[t]{5}{*}{$\mathrm{NaOH}-\mathrm{P}$} & FF & 0.5 & 0.6 & 0.6 & 0.3 & 0.7 & 0.4 & 0.5 & 0.1 \\
\hline & $\mathrm{FF}+1 \mathrm{~A}$ & 0.3 & 0.6 & 0.5 & 0.4 & 0.6 & 0.6 & 0.5 & 0.1 \\
\hline & $\mathrm{FF}+6 \mathrm{~A}$ & 0.7 & 1.1 & 0.8 & 0.7 & 0.8 & 0.9 & 0.8 & 0.1 \\
\hline & $\mathrm{FF}+7 \mathrm{~A}$ & 0.2 & 0.9 & 1.8 & 0.2 & 0.4 & 0.7 & 0.7 & 0.3 \\
\hline & $\mathrm{FF}+8 \mathrm{~A}$ & 0.5 & 0.6 & 1.0 & 0.2 & 0.4 & 0.6 & 0.5 & 0.1 \\
\hline \multirow[t]{8}{*}{ Insoluble residue } & $\mathrm{FF}$ & 14.4 & 12.3 & 13.3 & 10.9 & 8.3 & 5.8 & 10.8 & 1.4 \\
\hline & $\mathrm{FF}+1 \mathrm{~A}$ & 8.3 & 10.2 & 9.7 & 10.0 & 7.1 & 9.7 & 9.2 & 0.5 \\
\hline & $\mathrm{FF}+2 \mathrm{~A}$ & 11.6 & 31.4 & 14.6 & 12.8 & 13.4 & 11.5 & 15.9 & 3.4 \\
\hline & $\mathrm{FF}+3 \mathrm{~A}$ & 6.8 & 9.9 & 13.1 & 13.0 & 8.5 & 9.5 & 10.1 & 1.1 \\
\hline & $\mathrm{FF}+4 \mathrm{~A}$ & 15.3 & 18.5 & 7.4 & 11.0 & 12.4 & 13.2 & 13.0 & 1.7 \\
\hline & $\mathrm{FF}+5 \mathrm{~A}$ & 13.1 & 19.5 & 12.0 & 15.4 & 8.0 & 9.8 & 13.0 & 1.8 \\
\hline & $\mathrm{FF}+6 \mathrm{~A}$ & 14.8 & 23.3 & 13.7 & 8.3 & 9.2 & 9.2 & 13.1 & 2.5 \\
\hline & $\mathrm{FF}+7 \mathrm{~A}$ & 6.4 & 22.7 & 35.3 & 4.1 & 5.6 & 9.1 & 13.9 & 5.6 \\
\hline
\end{tabular}

$\overline{{ }^{\mathrm{E}} \mathrm{EtOH}-\mathrm{P}}=$ ethanol-soluble pectin, $\mathrm{WP}=$ water-soluble pectin, $\mathrm{HMP}=$ hexametaphosphoric acid-soluble pectin, $\mathrm{HCl}-\mathrm{P}=\mathrm{HCl}-\mathrm{soluble}$ pectin, $\mathrm{NaOOH}-\mathrm{P}=\mathrm{NaOH}$-soluble pectin.

${ }^{\mathrm{y}}$ Mean separation of each element between A. fistulosum and each monosomic addition lines by Dunnett's multiple test.

* Significant at $P \leq 0.05$.

sequence information from accession no. CF442750 was used for the forward primers, whereas accession no. CF451451 was used for the reverse primers.

PCR AMPlification ANd digestion of PCR PRoduct. PCR amplifications were conducted with template DNA [about $100 \mathrm{ng}$ of genomic DNA for the first PCR and $5 \mu \mathrm{L}$ of diluted template DNA (the products of the first PCR diluted 1/50 with sterile water) for the second PCR], each of the primers at $1 \mu \mathrm{M}, 0.25$ mM dNTPs, a $1 \times$ Ex Taq buffer, and $0.5 \mathrm{U}$ of Ex Taq polymerase (Takara Bio, Shiga, Japan) in a volume of $25 \mu \mathrm{L}$. All PCRs were performed as follows: an initial denaturation of $3 \mathrm{~min}$ at $94{ }^{\circ} \mathrm{C}$ and 35 cycles of PCR amplification (a 1-min denaturation at $94{ }^{\circ} \mathrm{C}$, a 1 -min annealing, and a 1 -min primer extension at $72{ }^{\circ} \mathrm{C}$ ) in a thermal cycler (iCycler; Bio-Rad, Hercules, CA). The ramp times were carried out under default conditions that adjusted temperature at the maximum ramp rate with the minimum ramp time. The annealing temperatures of the primer sets are given in Table 1. Nine microliters of the second PCR products was incubated for $2 \mathrm{~h}$ at $37^{\circ} \mathrm{C}$ in a volume of $15 \mu \mathrm{L}$ using $2 \mathrm{U}$ of a restriction enzyme and subsequently resolved by $5 \%$ denaturing polyacrylamide gel electrophoresis (PAGE) with silver staining according to the procedure of Martin et al. (2005). Restriction digestion with Bgl II (Toyobo, Osaka, Japan) was used to reveal polymorphisms.
Statistical Analyses. Data of the pectin content with different solubility in alternate months in the eight MALs and A. fistulosum were used for one-way analysis of variances (ANOVA). Dunnett's test was employed to compare the series of pectin contents between A. fistulosum and each MAL. Data of the alcohol-soluble carbohydrate content and the pectin content were used for principal component analyses (PCA). Statistic analyses were performed using SPSS 11.5 software with advanced models (SPSS Japan, Tokyo).

\section{Results and Discussion}

DETERMINATION OF ALCOHOL-SOLUBLE CARBOHYDRATE AND PECTIN CONTENTS IN MALs. The alcohol-soluble carbohydrate content in A. fistulosum and each MAL are shown in Table 2 and Fig. 1. The reducing sugar (fructose) contents remained constant throughout the year for all MALs. The fructose concentration in A. fistulosum was significant higher than that in each MAL. The seasonal changes of nonreducing sugar (sucrose and fructan) contents in A. fistulosum showed that they stayed high in winter and then decreased in spring and summer. These tendencies were almost the same as our previous study for which the sugar determinations were performed from Jan. 2002 to Dec. 2003 (Yaguchi et al., 2008b). In this study, 


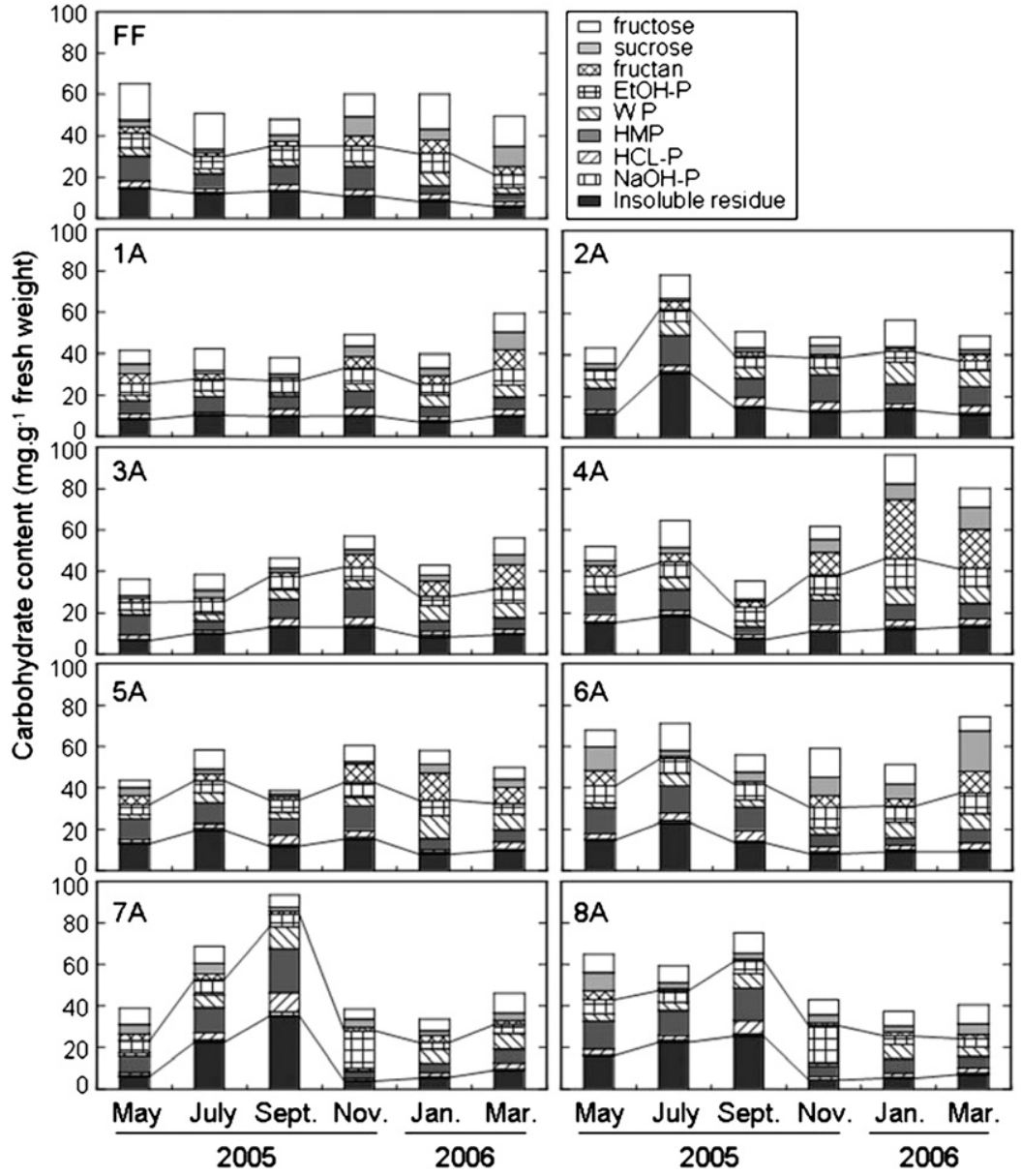

Fig. 1. The year-round variations of soluble and insoluble carbohydrate contents in a complete set of monosomic addition lines (1A-8A) compared with Allium fistulosum (FF) (EtOH-P = ethanol-soluble pectin, WP = watersoluble pectin, $\mathrm{HMP}=$ hexametaphosphoric acid-soluble pectin, $\mathrm{HCl}-\mathrm{P}=\mathrm{HCl}$-soluble pectin, and $\mathrm{NaOH}-\mathrm{P}=$ $\mathrm{NaOH}$-soluble pectin). Lines show the partitions between soluble sugars and pectins (upper) and between pectins and the insoluble residue (lower).

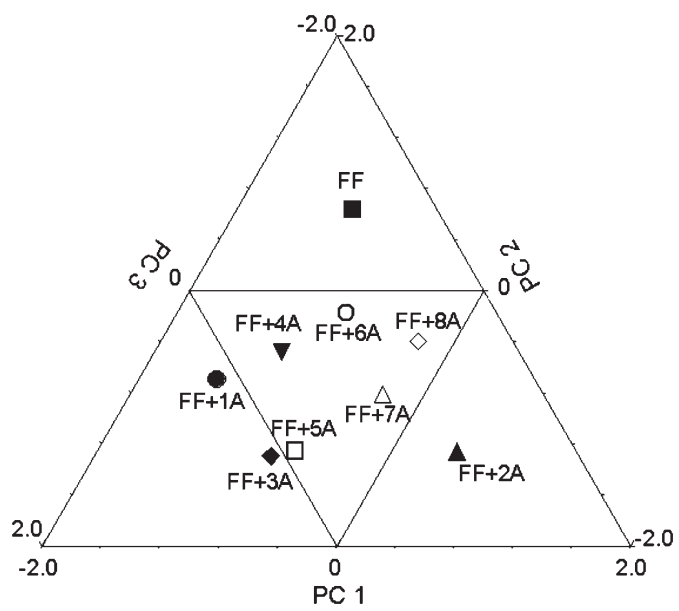

Fig. 2. Scores plot for three principal components (PC1-PC3) of the principal component analyses applied to the nine elements in the complete set of monosomic addition lines (FF+1A-FF+8A) and Allium fistulosum (FF).

seasonal changes of nonreducing sugar content in every MAL showed the same tendency as $A$. fistulosum, with the exception of fructan accumulation in FF+4A. The winter fructan contents in $\mathrm{FF}+4 \mathrm{~A}$ were significantly higher than that of A. fistulosum. Fructan is an important reserve carbohydrate in Allium L. species. In a previous study, no candidate genes related to fructan metabolism were assigned to chromosome 4A of shallot (Yaguchi et al., 2008b). This result indicates that anonymous genes controlling fructan accumulation are located on chromosome 4A of shallot.

The NaOH-P contents in A. fistulosum and every MAL were very low in every month of the year [average $0.6 \mathrm{mg} \cdot \mathrm{g}^{-1}$ fresh weight (FW) (Table 2 and Fig. 1)]. In HCl-P contents, A. fistulosum remained at low levels throughout the year (average $2.6 \mathrm{mg} \cdot \mathrm{g}^{-1} \mathrm{FW}$ ). All the MALs also remained at low levels of HCl-P contents in this study, except for $\mathrm{FF}+7 \mathrm{~A}$ and $\mathrm{FF}+8 \mathrm{~A}$ in Sept. 2005 (9.3 and $6.7 \mathrm{mg} \cdot \mathrm{g}^{-1}$ $\mathrm{FW}$, respectively). The seasonal change of the HMP content in $A$. fistulosum showed that this fraction was high from May to Nov. 2005 (average $9.8 \mathrm{mg} \cdot \mathrm{g}^{-1} \mathrm{FW}$ ) and then decreased from Jan. to Mar. 2006 (average $4.0 \mathrm{mg} \cdot \mathrm{g}^{-1} \mathrm{FW}$ ). In contrast, the seasonal change of the WP content in A. fistulosum showed that the WP remained at a low level from May to Nov. 2005 and then increased in January. Except for $\mathrm{FF}+7 \mathrm{~A}$ and $\mathrm{FF}+8 \mathrm{~A}$, all MALs showed the same tendency of HMP and WP accumulation as A. fistulosum. The greater accumulations of HMP in FF+7A and FF+8A were observed in Sept. 2005 (21.4 and $15.4 \mathrm{mg} \cdot \mathrm{g}^{-1} \mathrm{FW}$, respectively) and were twice or 1.5 times higher than that in $A$. fistulosum. In both HMP and WP contents, ANOVA revealed significant differences across the sampling times. In $\mathrm{FF}+7 \mathrm{~A}$ and $\mathrm{FF}+8 \mathrm{~A}$, the total pectin content substantially increased in Sept. 2005. In Nov. 2005, pectin contents extracted from AIS in FF+7A and FF+8A drastically decreased, whereas the EtOH-P contents drastically increased. The maximum EtOH-P accumulations in $\mathrm{FF}+7 \mathrm{~A}$ and $\mathrm{FF}+8 \mathrm{~A}$ were observed in Nov. 2005 and then decreased in Jan. 2006. The total pectin content of $\mathrm{FF}+7 \mathrm{~A}$ and $\mathrm{FF}+8 \mathrm{~A}$ substantially increased in Sept. 2005. Pectin biosynthesis requires the action of at least 53 different enzymatic activities (Mohnen, 1999). Therefore, several genes related to pectin biosynthesis may be concentrated on chromosomes 7A and 8A.

In A. fistulosum, mucilage, which are well-hydrated gels of cellulose, hemicellulose, and pectin, accumulated in the winter leaf blade (Inden and Asahira, 1990). The biosynthesis of the mucilage is poorly understood; a large amount of uronic acid, which consists mainly of L-galacturonic acid (Ohsumi and Hayashi, 1994), is present in the mucilage (Mizuno and Kinpyo, 1955). In FF+7A and FF+8A, the maximum EtOH-P accumulations were observed in Nov. 2005 and then decreased in Jan. 
2006. The degradation compounds of the pectin might be changed to mucilage by absorbing water. The mucilage content in the winter leaf blade of MALs was the highest in FF+8A (Hang et al., 2004). It was suggested that EtOH-P might be related to a change in the mucilage content in the winter leaf blade of $\mathrm{FF}+7 \mathrm{~A}$ and $\mathrm{FF}+8 \mathrm{~A}$.

ESTIMATION OF VARIATION ON ALCOHOL-SOLUBLE CARBOHYDRATE AND PECTIN CONTENTS IN MALS BY PRINCIPAL COMPONENT ANALYSES. Principal component analyses were conducted on the nine fractions measured in the $A$. fistulosum and each MAL. The first three principal components (PCs) explained $86.0 \%$ of the variation $(\mathrm{PC} 1=44.4 \%, \mathrm{PC} 2=26.0 \%$, PC3 $=15.6 \%)$. All MALs were plotted on a different position from that of $A$. fistulosum by using scores plot for three PCs (Fig. 2). The coefficient values of each carbohydrate parameter in the PC1, PC2, and PC3 are shown in Table 3. In PC1, a series of pectin derived from AIS showed high coefficient values, and each soluble carbohydrate displayed negative coefficient values. High coefficient values for PC2 were detected in the parameters of sucrose (0.91) and EtOH-P (0.91). In PC3, a high coefficient value was detected in fructan (0.77). Several parameters showed negative coefficient values for PC3. The largest negative value of PC3 was detected for fructose $(-0.56)$. From these parameters, PC2 and PC3 could be associated with a specific carbohydrate. On the other hand, the coefficient values of each carbohydrate parameter suggested that PC1 would be associated with alcohol-insoluble carbohydrate production, including pectin productions. Analyses of the carbohydrate composition in this study showed that the amounts of pectin in A. fistulosum and several MALs were comparable to the contents of soluble sugars. This result and PCA indicated that pectin would be one of the essential carbohydrates in A. fistulosum and that its composition was diverse in each MAL.

Chromosomal assignments of PME and PG Genes. Primers for the PME gene of $A$. cepa amplified a single band of $\approx 1000 \mathrm{bp}$ in $A$. fistulosum and shallot. After both PCR products were digested with the enzyme $B g l \mathrm{II}$, a polymorphism between $A$. fistulosum and shallot was detected. In the two complete sets of MALs, the restriction fragment length polymorphism (RFLP) from shallot was present only in FF+7A (Fig. 3a). This result revealed that the PME gene of the shallot is located on chromosome 7A. The primer set for the PG gene amplified a single band of $\approx 500 \mathrm{bp}$ in A. fistulosum and 550 bp in shallot. In MALs, the amplicon derived from shallot was present only in $\mathrm{FF}+4 \mathrm{~A}$ (Fig. 3b). This result revealed that the $P G$ gene of the shallot is located on the chromosome 4A.

PME de-esterifies the methyl group of pectin (Moustacas et al., 1991), whereas PG hydrolyzes the glycosidic linkages in pectic substances, significantly decreasing viscosity. The high activities of these pectin degradation enzymes increased the pectin solubilization and softening of the plant tissues (Bartolome and Hoff, 1972; Pilnik and Voragen, 1991). The decrease in the pectin content extracted from AIS in FF+7A (in Nov. 2005) could be caused by the high PME activity on chromosome 7A of shallot. A small decrease of the pectin content in FF+4A was observed in Sept. 2005. This suggested that the decrease of pectin content in $\mathrm{FF}+4 \mathrm{~A}$ may have been caused by the increase $\mathrm{PG}$ activity on chromosome $4 \mathrm{~A}$ of shallot in autumn. The EtOH-P content in FF+4A remained at a high level from Sept. 2005 to Mar. 2006 compared with the A. fistulosum. This indicated that the enzyme activities related to pectin degradation were high in $\mathrm{FF}+4 \mathrm{~A}$.

In the previous study, which observed seasonal changes of L-ascorbic acid content in MALs from Jan. 2002 to Dec. 2003, and three MALs, FF+1A, FF+2A, and FF+8A, were identified as having high ascorbic acid accumulation (Yaguchi et al., 2008a). The predominant pathway of ascorbic acid biosynthesis in plants is the D-mannose/L-galactose pathway (Smirnoff and

Table 3. Coefficient values of each carbohydrate parameter in the first to third principal component (PC1-PC3) revealed by the principal component analyses on the carbohydrate contents of Allium fistulosum and eight monosomic addition lines.

\begin{tabular}{lccr}
\hline Parameters $^{\mathrm{z}}$ & PC1 & PC2 & PC3 \\
\hline Fructose & -0.35 & 0.57 & -0.56 \\
Sucrose & -0.21 & 0.91 & -0.06 \\
Fructan & -0.29 & 0.32 & 0.77 \\
EtOH-P & -0.09 & 0.91 & 0.07 \\
WP & 0.94 & -0.12 & 0.25 \\
$\mathrm{HMP}$ & 0.90 & 0.04 & -0.30 \\
$\mathrm{HCl}-\mathrm{P}$ & 0.88 & 0.32 & -0.18 \\
NaOH-P & 0.64 & 0.34 & 0.53 \\
Insoluble residue & 0.93 & 0.16 & -0.13 \\
\hline
\end{tabular}

$\overline{{ }^{\mathrm{z}} \mathrm{EtOH}-\mathrm{P}=\text { ethanol-soluble pectin, } \mathrm{WP}=\text { water-soluble pectin, } \mathrm{HMP}=}$ hexametaphosphoric acid-soluble pectin, $\mathrm{HCl}-\mathrm{P}=\mathrm{HCl}$-soluble pectin, $\mathrm{NaOH}-\mathrm{P}=\mathrm{NaOH}$-soluble pectin.

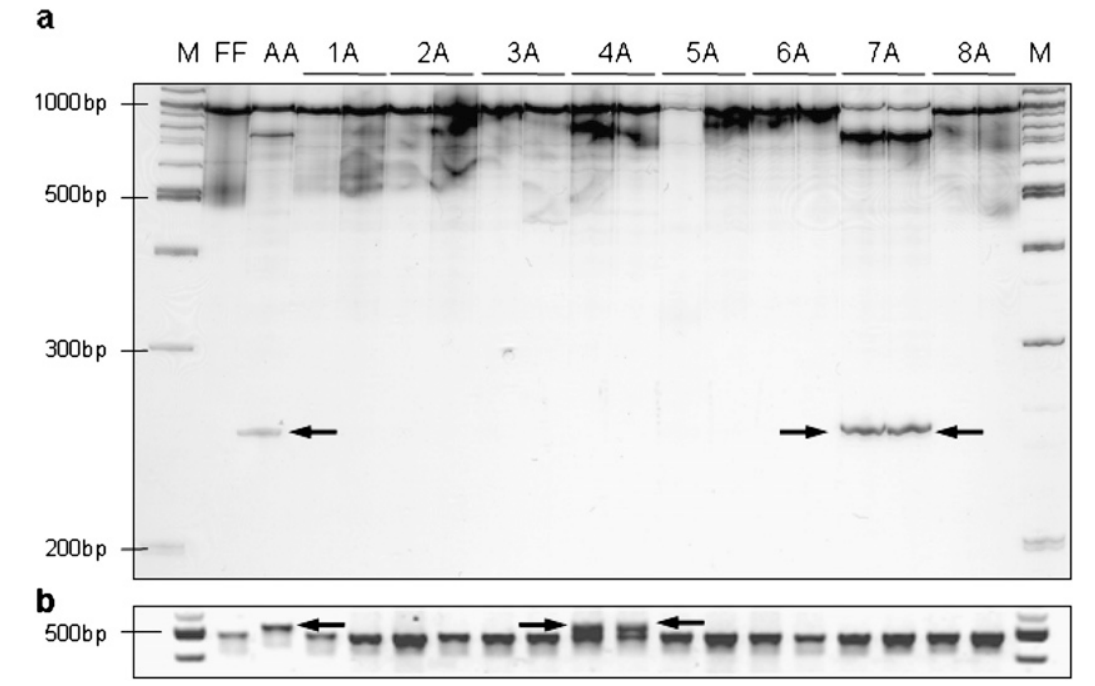

Fig. 3. Electropherograms showing the chromosomal location of pectin methylesterase (a) and polygalacturonase (b) genes in shallot $[\mathrm{FF}=$ Allium fistulosum, $\mathrm{AA}=$ shallot, $1 \mathrm{~A}-8 \mathrm{~A}=$ two complete sets of $A$. fistulosum - shallot monosomic addition lines, and $\mathrm{M}=$ molecular size marker (100-bp DNA ladder)]. Arrows point to the shallotspecific band. 
Gatzek, 2004; Wheeler et al., 1998). However, any other biosynthetic pathway via uronic acid intermediates may exist. The molecular evidence for this pathway (i.e., a D-galacturonic acid pathway) was provided by the cloning and characterization of a D-galacturonic acid reductase from strawberry [Fragaria $\times$ ananassa Duchesne (Agius et al., 2003)]. We proposed that D-galacturonic acid derived from pectin was reduced to L-galacturonic acid, which in turn is readily converted to ascorbic acid. We hypothesize that the rapid decrease in the pectin content of $\mathrm{FF}+8 \mathrm{~A}$ increased an endogenous ascorbic acid production via the D-galacturonic acid pathway. The carbohydrates derived from pectin degradation would be reused to produce an ascorbic acid in A. fistulosum and MALs, while the rapid decrease in the pectin content derived from AIS of FF+8A in November resulted in an increase in endogenous ascorbic acid production via the D-galacturonic acid pathway.

Several MALs displayed peculiar nondigestible carbohydrate composition, which could be used to breed for increasing specific pectin contents in A. fistulosum via the use of the MAL chromosome doubling program (Yaguchi et al., 2008a). The clarification of the pectin phenotypes in MALs and the chromosomal locations of shallot genes related to the pectin metabolism provide a more detailed understanding of the genes underlying carbohydrate phenotypes. This should be combined with an analysis of quantitative trait locus (QTL) related to a variation in $A$. cepa carbohydrate composition. An initial QTL analysis in $A$. cepa identified several genomic regions affecting dry matter content, soluble solids, and other correlated traits (Galmarini et al., 2001). A subsequent study based on this QTL analysis confirmed that two QTL affecting soluble solids and dry matter content were associated with two different RFLP markers, which are candidate genes of an acid invertase on chromosome 3 (Havey et al., 2004) and a phloem-unloading sucrose transporter on chromosome 5 (Martin et al., 2005), respectively. Marker assisted selections via the usages of the key candidate genes mapped along with several QTLs affecting carbohydrate traits together with other candidate genes for pectin metabolism would provide a possibility to control nondigestible carbohydrate contents in the bulb of $A$. серa. As a result, consumers might receive a health benefit through a diet including novel onion ( $A$. cepa Common onion group) and shallot cultivars possessing high concentrations of nondigestible carbohydrates.

\section{Literature Cited}

Agius, F., R. González-Lamothe, J.L. Caballero, J. Muñoz-Blanco, M.A. Botella, and V. Valpuesta. 2003. Engineering increased vitamin $\mathrm{C}$ levels in plants by overexpression of a D-galacturonic acid reductase. Nat. Biotechnol. 21:177-181.

Bartolome, L.G. and J.E. Hoff. 1972. Firming of potatoes: Biochemical effects of preheating. J. Agr. Food Chem. 20:266-270.

Behall, K. and S. Reiser. 1986. Effects of pectin on human metabolism, p. 248-265. In: M.L. Fishman and J.J. Ren (eds.). Chemistry and functions of pectins. American Chemical Society, Washington, DC. Brady, C.J. 1987. Fruit ripening. Annu. Rev. Plant Physiol. 38:155178.

Campbell, A.D., M. Huysamer, H.U. Stotz, L.C. Greve, and J.M. Labavitch. 1990. Comparison of ripening processes in intact tomato fruit and excised pericarp discs. Plant Physiol. 94:1582-1589.

Femenia, A., P. Garosi, K. Roberts, K.W. Waldron, R.R. Selvendran, and J.A. Robertson. 1998. Tissue-related changes in methyl-esterification of pectic polysaccharides in cauliflower (Brassica oleracea L. var. botrytis) stems. Planta 205:438-444.
Filisetti-Cozzi, T.M.C.C. and N.C. Carpita. 1991. Measurement of uronic acids without interference from neutral sugars. Anal. Biochem. 197:157-162.

Galmarini, C.R., I.L. Goldman, and M.J. Havey. 2001. Genetic analyses of correlated solids, flavor, and health-enhancing traits in onion (Allium cepa L.). Mol. Genet. Genomics 265:543-551.

Hang, T.T.M., M. Shigyo, S. Yaguchi, N. Yamauchi, and Y. Tashiro. 2004. Effect of single alien chromosome from shallot (Allium cepa L. Aggregatum group) on carbohydrate production in leaf blade of bunching onion (A. fistulosum L.). Genes Genet. Syst. 79:345350.

Havey, M.J., C.R. Galmarini, A.F. Gokce, and C. Henson. 2004. QTL affecting soluble carbohydrate concentrations in stored onion bulbs and their association with flavor and health-enhancing attributes. Genome 47:463-468.

Huber, D.J. 1983. The role of cell wall hydrolases in fruit softening. Hort. Rev. (Amer. Soc. Hort. Sci.) 5:169-219.

Inden, H. and T. Asahira. 1990. Japanese bunching onion (Allium fistulosum L.), p. 159-178. In: H.D. Rabinowitch and J.L. Brewster (eds.). Onion and allied crops, Vol. III. CRC Press, Boca Raton, FL. Martin, W., J. McCallum, M. Shigyo, J. Jakse, J. Kuhl, N. Yamane, M. Pither-Joyce, A. Gokce, K. Sink, C. Town, and M. Havey. 2005. Genetic mapping of expressed sequences in onion and in silico comparisons with rice show scant colinearity. Mol. Genet. Genomics 274:197-204.

Mizuno, T. and T. Kinpyo. 1955. Studies on the carbohydrates of Allium. I. Kinds of carbohydrates of Allium fistulosum L. Nippon Nogeikagaku Kaishi 29:665-671 (In Japanese with English abstract).

Mohnen, D. 1999. Biosynthesis of pectins and galactomannans, p. 497-527. In: B.M. Pinto (ed.). Comprehensive natural products chemistry, Vol. 3, Carbohydrates and their derivatives including tannins, cellulose, and related lignins. Elsevier, Oxford, UK.

Moustacas, A.M., J. Nari, M. Borel, G. Noat, and J. Ricard. 1991. Pectin methylesterase, metal ions and plant cell-wall extension. The role of metal ions in plant cell-wall extension. Biochem. J. 279:351354.

Ohsumi, C. and T. Hayashi. 1994. Carbohydrate analysis of an interspecific hybrid between onion and garlic. Biosci. Biotechnol. Biochem. 58:959-960.

Olano-Martin, E., G.H. Rimbach, G.R. Gibson, and R.A. Rastall. 2003. Pectin and pectic-oligosaccharides induce apoptosis in in vitro human colonic adenocarcinoma cells. Anticancer Res. 23:341-346.

Percheron, F. 1962. Dosage colorimetrique du fructose et des fructofuranosides par 1' acide thiobarbiturique. C.R. Acad. Sci. 255:25212522.

Pilnik, W. and A.G.J. Voragen. 1991. The significance of endogenous and exogeneous pectic enzymes in fruit and vegetable processing, p. 303-309. In: P.F. Fox (ed.). Food enzymology. Elsevier Science Publishers, Belfast, UK.

Ridley, B.L., M.A. O’Neill, and D.A. Mohnen. 2001. Pectins: Structure, biosynthesis, and oligogalacturonide-related signaling. Phytochemistry 57:929-967.

Sakurai, N. and D.J. Nevins. 1993. Changes in physical properties and cell wall polysaccharides of tomato (Lycopersicon esculentum) pericarp tissues. Physiol. Plant 89:681-686.

Sapers, G.M., P.H. Cooke, A.E. Heidel, S.T. Martin, and R.L. Miller. 1997. Structural changes related to texture of pre-peeled potatoes. J. Food Sci. 62:797-801.

Shigyo, M., M. Iino, S. Isshiki, and Y. Tashiro. 1997. Morphological characteristics of a series of alien monosomic addition lines of japanese bunching onion (Allium fistulosum L.) with extra chromosomes from shallot (A. cepa L. Aggregatum group). Genes Genet. Syst. 72:181-186.

Shigyo, M., Y. Tashiro, S. Isshiki, and S. Miyazaki. 1996. Establishment of a series of alien monosomic addition lines of japanese bunching onion (Allium fistulosum L.) with extra chromosomes from shallot (A. cepa L. Aggregatum group). Genes Genet. Syst. 71:363371. 
Smirnoff, N. and S. Gatzek. 2004. Ascorbate biosynthesis: A diversity of pathways, p. 7-29. In: H. Asard, J.M. May, and N. Smirnoff (eds.). Vitamin C. Functions and biochemistry in animals and plants. BIOS Scientific Publishers, Oxford, UK.

van Heusden, A.W., J.W. van Ooijen, R. Vrielink-van Ginkel, W.H.J. Verbeek, W.A. Wietsma, and C. Kik. 2000. A genetic map of an interspecific cross in Allium based on amplified fragment length polymorphism (AFLP ${ }^{T M}$ ) markers. Theor. Appl. Genet. 100:118-126. Wheeler, G.L., M.A. Jones, and N. Smirnoff. 1998. The biosynthetic pathway of vitamin C in higher plants. Nature 393:365-369.

Willats, W.G.T., J.P. Knox, and J.D. Mikkelsen. 2006. Pectin: New insights into an old polymer are starting to gel. Trends Food Sci. Technol. 17:97-104.
Yaguchi, S., J. McCallum, M. Shaw, M. Pither-Joyce, S. Onodera, N. Shiomi, N. Yamauchi, and M. Shigyo. 2008b. Biochemical and genetic analysis of carbohydrate accumulation in Allium cepa L. Plant Cell Physiol. 49:730-739.

Yaguchi, S., M. Atarashi, M. Iwai, S. Masuzaki, N. Yamauchi, and M. Shigyo. 2008a. Production of alien addition lines in polyploid bunching onion (Allium fistulosum) carrying 1A chromosome(s) of shallot (Allium cepa) and their application to breeding for a new vitamin C-rich vegetable. J. Amer. Soc. Hort. Sci. 133:367-373.

Yamada, H. 1996. Contribution of pectins on health care, p. 173-190. In: J. Visser and A.G.J. Voragen (eds.). Pectins and pectinases. Elsevier, Amsterdam, The Netherlands. 